\title{
The production of biogas from palm oil mill effluent as substrate with variation of agitation speed with fed-batch system
}

\author{
Martha Aznury ${ }^{1, *}$, Jaksen $^{1}$, Abu $\operatorname{Hasan}^{1}$, Ralli Artindah ${ }^{1}$ \\ ${ }^{1}$ Department of Chemical Engineering, Politeknik Negeri Sriwijaya, Palembang Jl. Srijaya Negara Bukit Besar,Palembang 30139, \\ Indonesia
}

\begin{abstract}
The purpose of this research is to determine the effect of variation of agitation speed on biogas production from palm oil mill effluent and cow dung as substrate by using modified digester fed-batch. The addition of agitation in the fermentation tank digester in this research to accelerate the contact between the microorganisms with the substrate so that the process runs more effectively. Thus biogas production with variations of agitation velocity have 90 and $102 \mathrm{rpm}$. The research is conducted by fed-batch that is the addition of substrate in fermentation tank as much as 1 liter for 2 days which aim to get optimum biogas production result. The results of this research indicate that the speed of agitation affects for biogas production. The optimum biogas production occurred at $102 \mathrm{rpm}$ agitation speed after 30 days fermentation time was $26.5116 \% \mathrm{~mol} \mathrm{CH}_{4}$.
\end{abstract}

\section{Introduction}

Palm oil mill effluent (POME) is one of the most frequent agro-industrial liquid wastes causing pollution. Liquid wastes from these palm oil mills are generally high-temperature $70-80^{\circ} \mathrm{C}$, brownish, containing dissolved solids and suspended colloids and high oil residues with biological oxygen demand (BOD) and chemical oxygen demand (COD). The colloidal suspension of POME in PT Mitra Ogan was containing $92-96 \%$ water; $0.5-0.7 \%$ oil and fat, and $3-7 \%$ total solids [1]. Palm oil production requires large amounts of water. One tonne of palm oil produces was derived by 3 tons of POME [2], which is liquid waste derived from water input in separation, clarification and sterilization processes. If POME is immediately discharged into the water, some will settle, break down slowly, consume dissolved oxygen, cause turbidity, emit a sharp odour and can damage the aquatic ecosystems due to the long decomposition process. Before this liquid waste can be discharged into the environment it must first be processed to conform to the waste quality standard set by the environmental agency.

POME is a nutrient rich in organic compounds and carbon, decomposition of organic compounds by anaerobic bacteria can produce biogas [3]. If these gases are not managed and allowed to escape into the open air it can be one of the causes of global warming because the released methane and carbon dioxide gas is including a greenhouse gas that is touted as a source of current global warming. Methane gas $\left(\mathrm{CH}_{4}\right)$ emissions are 21 times more dangerous than carbon dioxide $\left(\mathrm{CO}_{2}\right)$ and methane is one of the largest greenhouse gas [4].
In this research, there is an idea to optimally process POME by creating a tool that represents the modelling system in industrial waste ponds, so it is expected to provide more benefits in treating waste. This research applies the principle of processing done by sedimentation and fermentation process [5], in the hope that the result of waste treatment is discarded without exploiting its content by using modified digester as modification of truncated pyramid and beam [4 and 6].

\section{Materials and methods}

\subsection{Materials and process}

Raw material and process fermentation with the method from Aznury et.al. [6]. This research was conducted to produce biogas from POME and activator microorganisms as a substrate to the addition of variation of agitation in digester tool. The parameters observed in producing biogas are $\mathrm{CH}_{4}, \mathrm{CO}_{2}, \mathrm{H}_{2} \mathrm{~S}$ and $\mathrm{O}_{2}$.

\subsection{Experimental set-up}

The feeding tank will be flowed by the pump to a truncated pyramid digester (tank A) and after the full tank, A is allowed to stand for 24 hours for the sedimentation process. Then, open the valve that is in the middle of tank A and tank B and drain into the tank B for the fermentation process for $\mathrm{CH}_{4}$ gas formation.

\footnotetext{
*Corresponding author: martha_aznury@polsri.ac.id
} 


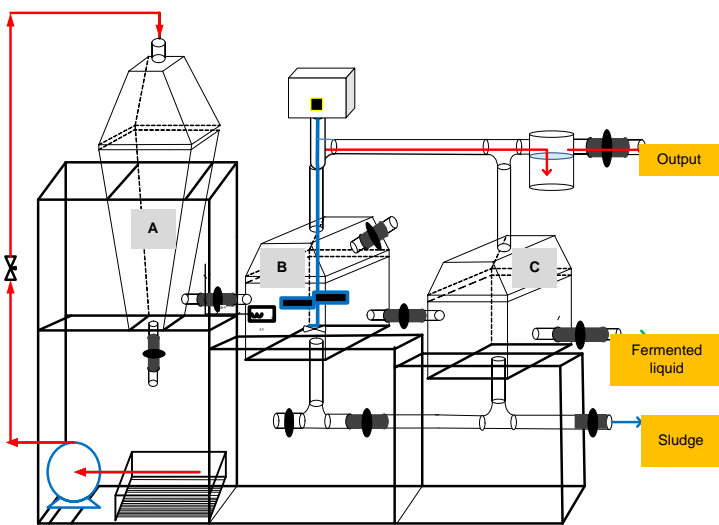

Figure 1. Design Modification Digester

The feed flow rate of $6 \mathrm{~L} / \mathrm{min}$ and the sedimentation time for 24 hours, the mud and water will be separated after the residence time of 24 hours, the mud and water are separated to analyze the quality of POME processing as the initial waste data before the process fermentation. This is done so as not to block the mud in the next tank (tank B).

After the fermentation process in the tank B, it is then channelled to the tank $\mathrm{C}$ for final processing before the feed in the form of POME is discharged into the environment. At the top of the tank $\mathrm{B}$ and $\mathrm{C}$ is provided with a cover which is accompanied by a swan neck containing $\mathrm{NaOH}$ which will absorb the $\mathrm{CO}_{2}$ content in the gas flowing to the $\mathrm{CH}_{4}$ gas shelter formed and the sides are equipped with filter paper to filter the water formed for then accommodated. As for the bottom product of mud will be issue after some time.

This research begins with preparing a feed of POME. The bait stored in the storage tank is loaded into the feeder until it is full. POME that has been separated from the sediment sludge due to the sedimentation process will be channelled to tank $\mathrm{B}$ and $\operatorname{tank} \mathrm{C}$ with the addition of one-litre substrate per day given on tank B with 70:30 ratio where $70 \%$ POME and starter in the form of mixture $30 \%$. The tank B bait for $30^{\text {th }}$ days consisted of $9^{\text {th }}$ days of feed on tank B flowed to tank C every two days 1 time as much as 2 litres, but on the $9^{\text {th }}$ day the feed was added to 3 litres into tank $\mathrm{C}$ and the total volume was 19 litres. For research fed-batch fermentation will be regular substrate addition that is every two days 1 time as much as 1 litre in tank B without any output. During the fermentation process, the result is obtained gas in the tedler bag. After 30 days the fermentation process is complete the samples in each treated tank will be taken for analysis of the content of TDS, TSS, COD, BOD, and $\mathrm{pH}$.

\subsection{Analytical}

Raw POME and fermented POME was analyzed by the American Public Health Association [7]. Biogas was analyzed by using using a gas chromatograph (GC-8A, Shimadzu, Kyoto).

\section{Results and discussion}

\subsection{Analysis of raw materials}

Processing raw materials in the form of POME using the modification of digester through the stages of sedimentation and fermentation process. Before getting treatment, the first waste will be examined the initial content of the waste to determine the waste container. The following is an initial analysis of the POME which can be seen in Table 1.

Table 1. Preliminary Analysis of POME

\begin{tabular}{llll}
\hline No & Parameters & Analysis results & $\begin{array}{l}\text { The maximum } \\
\text { limit allowed }\end{array}$ \\
\hline 1 & TDS & $281 \mathrm{mg} / \mathrm{L}$ & - \\
2 & TSS & $243 \mathrm{mg} / \mathrm{L}$ & $250 \mathrm{mg} / \mathrm{L}$ \\
3 & $\mathrm{pH}$ & 4.55 & $6-9$ \\
4 & BOD & $117 \mathrm{mg} / \mathrm{L}$ & $100 \mathrm{mg} / \mathrm{L}$ \\
5 & COD & $345 \mathrm{mg} / \mathrm{L}$ & $350 \mathrm{mg} / \mathrm{L}$ \\
\hline
\end{tabular}

Table 1 shows that the initial content of the palm oil industry's wastewater obtained for $\mathrm{pH}$ and BOD values exceeds the quality standard established under Governor Regulation No. 8 of 2012 on the Standard of Waste for the Palm Oil Industry [8]. The COD and TSS values contained in the initial POME did not exceed the standards permitted by the Governor Regulation of South Sumatera No. 8 of 2012 on the quality standard of liquid waste for the palm oil industry is a maximum of $350 \mathrm{mg} / \mathrm{L}$ for COD and $250 \mathrm{mg} / \mathrm{L}$ for TSS. Whereas for BOD and $\mathrm{pH}$ values in POME waste exceeded the permitted standard, the BOD value contained in POME $117 \mathrm{mg} / \mathrm{L}$ waste with a maximum limit of $100 \mathrm{mg} / \mathrm{L}$. The $\mathrm{pH}$ is still within the acid of 4.55 and for the limit is 6-9. This is because the content of COD, BOD, TSS, TDS, and $\mathrm{pH}$ for each of the oil palm wastewater is different according to the source of the POME waste. Sometimes the results vary between good and bad waste. It is not possible to not do waste treatment because there is still some content that exceeds the threshold value.

The wastewater treatment of POME in Indonesia is generally processed with an open pond system, hereinafter called conventional system, consisting of three phases: precipitation, anaerobic pool, and aerobics pool. Handling waste by such methods requires large areas of land and high costs, without any other benefits. Generally, liquid waste management of palm oil mills is applied biologically, which is channelled into reservoir ponds before finally entering the public water body, the waste disposed of is still above a predetermined threshold. Wastewater generated as a whole is a potent liquid mixture as a source of the pollutant. In addition, $\mathrm{O}_{2}$ gases, greenhouse gas emissions, and other gases have the potential to cause negative impacts on the environment, especially the large contribution to the risk of global warming and climate change. This underlying research to utilize methane gas as biogas in conventional anaerobic ponds was replaced by a closed pool system. Digester serves to replace an anaerobic pool in a 


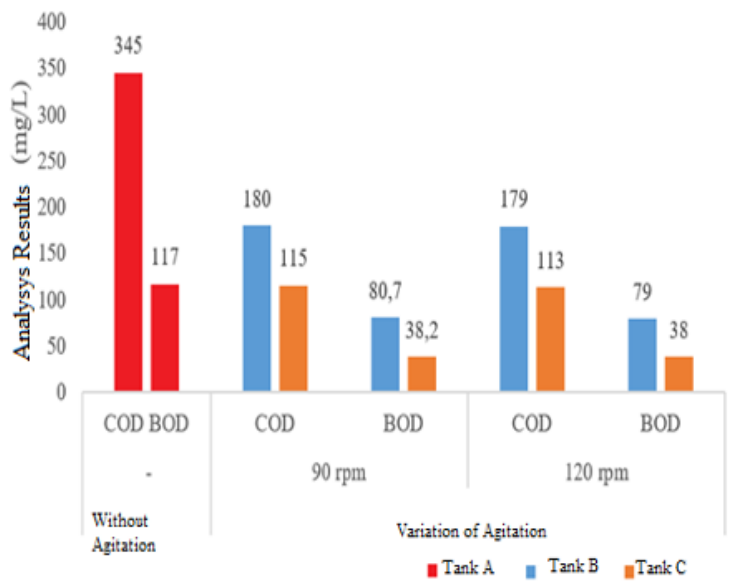

Figure 2. Effect of Agitation Speed on Chemical Content Analysis Oxygen Demand (COD) and Biological Oxygen Demand (BOD)

conventional system assisted by the use of bacteria for decomposition of waste organic compounds in producing biogas.

Modified digester refers to previous research that has been done [4 and 6]. However, the previous design was inefficient, since the previous design had the same tank shape, but in the fermentation tank, there was no stirring so it would take a little time to contact between the substrate and the microorganism. Sedimentation tank that is used as a pyramid-shaped design that can make the sedimentation process quickly. While the fermentation tank on the modified beam-shaped digester with the addition of agitation is able to perform the fermentation process well and quickly because the contact between the substrate with the microorganism becomes more effective. In addition, agitation can also avoid the formation of sediments in the digester which can inhibit the production of biogas. Modifications to the digester are carried out to develop a fed-batch waste treatment process. From the statement, it is necessary treatment in the form of waste treatment in modified digester so that the organic content in the waste can be degraded into sludge or can be used as another product in the form of biogas.

\subsection{POME analysis after treatment}

The result of COD value obtained from fermentation process of palm oil waste or POME for 30 days at tank B was $180 \mathrm{mg} / \mathrm{L}$ for agitating speed of $90 \mathrm{rpm}$ and for agitation speed $102 \mathrm{rpm}$ obtained COD value of 179 $\mathrm{mg} / \mathrm{L}$, where COD value is far lower when compared with Aznury, et al [4] with fermentation time of 10 days with COD value obtained $362 \mathrm{mg} / \mathrm{L}$. From the COD value data, it can be seen that the COD value is determined based on the type of POME itself which means that the COD value of each oil palm liquid waste varies based on the source of the POME waste and the fermentation time greatly influences the reduced COD content. While for BOD value after fermentation 30 days was $80.7 \mathrm{mg} / \mathrm{L}$ for agitation speed $90 \mathrm{rpm}$ and BOD value $79 \mathrm{mg} / \mathrm{L}$ for speed agitation $102 \mathrm{rpm}$ which value still lower when compared with the result of research by Aznury, et.al [4] have value BOD $125.3 \mathrm{mg} / \mathrm{L}$.

In this research, the results of COD, BOD, TSS and TDS content analysis in POME after anaerobic fermentation process for 30 days have met the standard quality standard for which has been established based on the governor regulation of South Sumatra No. 8 of 2012 on the quality standard of liquid waste for the palm oil industry [8]. So that liquid waste can be directly discharged into the river or to the recipient body of water.

\subsubsection{Effect of agitation variation on $C O D$ and $B O D$}

The purpose of the addition of agitation in tank B for modification of this digester is to accelerate the contact between the substrate with the microorganisms become larger so that the microorganisms easily and much decompose organic materials and decrease the value of COD. The use of agitation during the study is only 15 minutes per day because of the excessive use of agitation will disrupt microbial activity. In this research, agitation has an effect on the result of COD and BOD content analysis. Effect of agitation on the content of COD and BOD from the results of the study can be seen in Fig. 2.

Fig. 2 shows that agitation speed is very influential for COD and BOD values. The content of BOD value in tank A without agitation still exceeds the permitted threshold while COD has met the permissible condition. Since this is the initial content of the waste, so there is a need for processing to reduce the value of COD and BOD in POME waste. In Fig. 2 it can be observed that after the waste treatment in the tank B and tank C in the presence of agitation speed of $90 \mathrm{rpm}$ then there is a decrease in the value of COD and BOD. The COD value of $345 \mathrm{mg} / \mathrm{L}$ before treatment (without agitation) to 180 $\mathrm{mg} / \mathrm{L}$ for tank B then fell back to $115 \mathrm{mg} / \mathrm{L}$ in tank C after treatment. While the BOD value before the treatment was $117 \mathrm{mg} / \mathrm{L}$ indicating the $\mathrm{BOD}$ value exceeded the permitted threshold of $100 \mathrm{mg} / \mathrm{L}$. Furthermore, the BOD value also decreased up to 80.7 $\mathrm{mg} / \mathrm{L}$ in tank B and fell back in the $\mathrm{C}$ tank to $38.2 \mathrm{mg} / \mathrm{L}$. For the agitation speed of $102 \mathrm{rpm}$ is the same at $90 \mathrm{rpm}$, the COD and BOD value is almost the same. This is because the composition used is the same as the $70 \%$ POME and $30 \%$ substrate ratio.

The occurrence of COD and BOD decrement during the given agitation variation means that the substrate has been dispersed or mixed (homogeneously) with microbes, thus affecting microbial work in removing or reducing organic compounds. The greater the reduction of COD, the organic matter degraded into organic acids is also greater. These organic acids are then converted into biogas, so if the COD reduction is greater and the rate of biogas formation is also greater [9].

\subsubsection{Analysis of agitation effect on biogas production}

Biogas is clean and renewable energy that can be an alternative to conventional energy sources that can cause 
problems for the environment and increase the rate of energy depletion in a long time. The process of biogas formation requires a special installation called a digester, its function is that anaerobic reshuffle can take place well. The process of organically changing anaerobic materials consists of four stages of the process of hydrolysis, acidogenesis, acetogenesis and methanogenesis.

Therefore, this research treats POME to reduce the harmful chemical compounds content of POME by utilizing the resulted products from the processing of sludge and biogas (methane gas) by using pyramid-beam shaped digester with the addition of agitation. The agitation treatment was performed to obtain a homogeneous substrate and starter composition in the reactor. Agitation is also done to prevent the occurrence of floating objects on the liquid surface and to obtain a uniform temperature at the reactor. Stirring in this study was done once a day and was done during the day for 15 minutes. The analysis obtained for the effect of agitation with a speed of $90 \mathrm{rpm}$ on the production of biogas on the modification of digester fed-batch can be seen in Fig. 3.

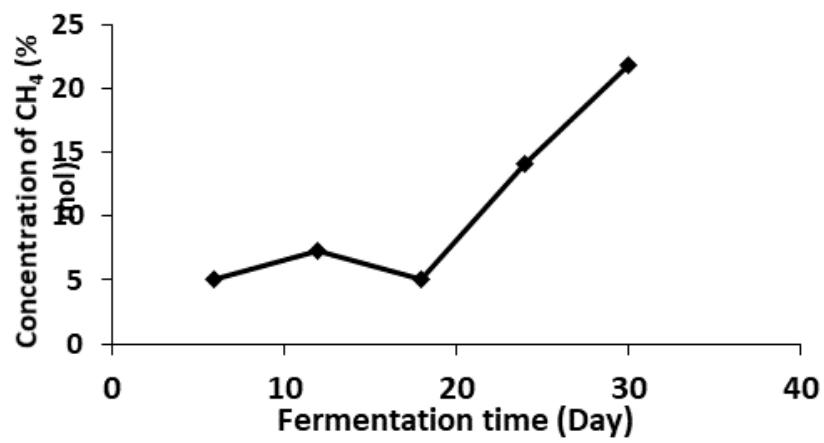

Figure 3. $\mathrm{CH}_{4}$ Concentration in Fermentation with $90 \mathrm{Rpm}$

In Fig. 3 above can be observed the effect of Agitation Speed $90 \mathrm{rpm}$ on $\mathrm{CH}_{4}$ produced. $\mathrm{CH}_{4}$ data retrieval at fermentation time for $6^{\text {th }}$ days, 12 days, 18 days, 24 days and 30 days. Initially, there was an increase of $\% \mathrm{CH}_{4}$ production on the $6^{\text {th }}$ day by $5.0234 \%$ mole and the $12^{\text {th }}$ day was $7.312 \%$ mole. Decrease in $\mathrm{CH}_{4}$ production on the $18^{\text {th }}$ day due to leakage in the sampling bag (gas container) so that obtained a little. Increased $\mathrm{CH} 4$ production was significant to $14.1043 \%$ more on day 24 so that the peak reached on the $30^{\text {th }}$ day was $21.8097 \%$ mole. The occurrence of increased production of biogas indicates that the activity of the bacteria goes well.

As for the effect of agitation velocity on biogas production result, Fig. 4 below is the effect of agitation speed $102 \mathrm{rpm}$ on $\mathrm{CH}_{4}$ concentration produced.

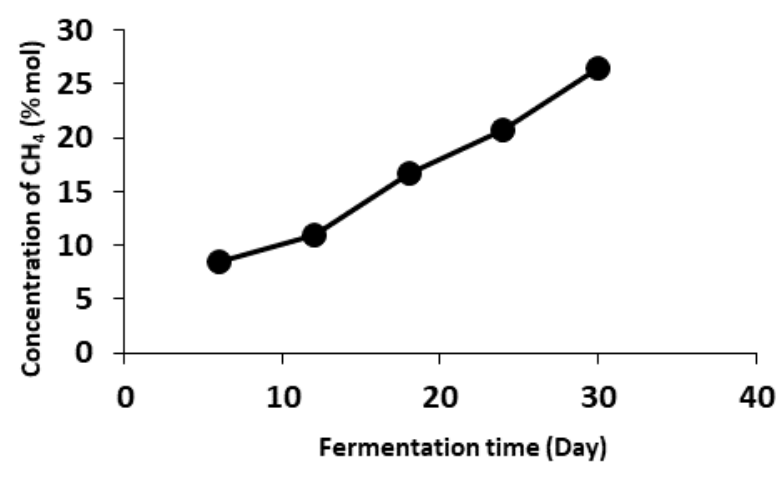

Figure $4 \mathrm{CH}_{4}$ Concentration in Fermentation with $102 \mathrm{rpm}$

Fig. 4 can be observed the effect of agitation speed $102 \mathrm{rpm}$ on $\mathrm{CH}_{4}$ produced. The agitation speed of 102 rpm produces more biogas than agitation speed of 90 $\mathrm{rpm}$. At the beginning of the product on 6th fermentation produced $\mathrm{CH}_{4}$ as much as $8.4845 \%$ mole while for the speed of $90 \mathrm{rpm}$ produced only equal to $5.0234 \%$ mole. Further of fermentation time are $12^{\text {nd }}, 18^{\text {th }}, 24^{\text {th }}$ and $30^{\text {th }}$ days continue to increase of $\mathrm{CH}_{4}$. At day $30^{\text {th }}$ is the peak of biogas product that is $26.5116 \%$ mole $\mathrm{CH}_{4}$, this result is higher than agitation speed of $90 \mathrm{rpm}$ which equal to $21.8097 \%$ mole $\mathrm{CH}_{4}$. According to Mujdalipah, et al [10], fermentation time gives a significant difference to gas production, where fermentation time has a direct effect on biogas production. So the gas volume increases with increasing fermentation time.

Biogas production in this study achieved optimal results on the $30^{\text {th }}$ day of producing $26.5116 \%$ mole $\mathrm{CH}_{4}$ gas obtained from the fermentation process with a concentration of $30: 70 \%$ substrate by fed-batch. This indicates that the substrate is maximally converted completely into biogas. As the number of bacterial populations increases, bacterial activity produces $\mathrm{CH}_{4}$ also increases to produce $\mathrm{CH}_{4}$ with a larger composition. The speed of agitation is highly influential for biogas products because the faster the agitation the contacts between substrate and microorganisms are more efficient and the process also works better and faster. But the speed of agitation is also very bad for biogas products because if excessive agitation speed will cause bacterial activity to be disturbed.

\subsubsection{Comparison of biogas production results from $P O M E$ processing with fed-batch system}

Biogas production is obtained from the fermentation process of POME in the reactor, where the fermentation system used is the fed-batch process. According to Widjaja [11], the fed-batch system is a system that adds new media regularly to the closed culture that exists in the reactor so that the volume of culture is increasingly increasing. According to Rusmana [12], the fed-batch method of introducing some sources of nutrients into bioreactors with a certain volume to obtain a product that is close to maximum, but the concentration of nutrients source is made constant. Comparison of biogas production results from previous researchers can be seen in Table 2. 
Table 2. Comparison of Biogas Production Results on a fedbatch basis with Previous Research

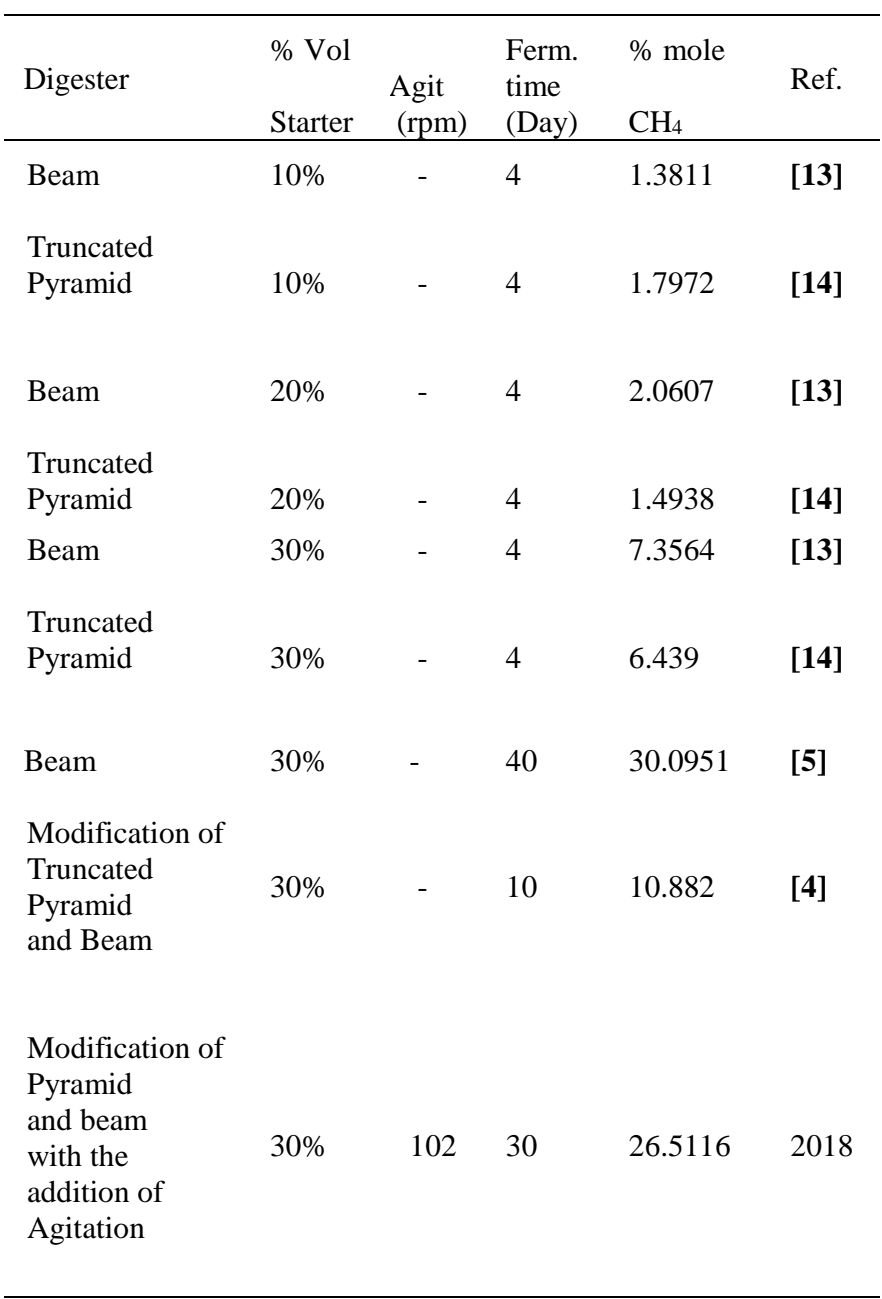

From Table 2 shows the beam-shaped digester produces more biogas than the pyramid-shaped diets. The pyramid-shaped digester is more efficient in the process of sedimentation than the beam digester seen from the production of $\mathrm{CH}_{4}$ by Aznury, et al [4] which is $10.8817 \%$ in fermentation time for 10 days.

The biogas production results from the Fahlevi [14], Saputri [13], and Aznury, et al [4] studies are still below the biogas production by modified digester with the addition of agitation obtained by $26.5116 \%$ mole $\mathrm{CH}_{4}$ in fermentation time for 30 days. The longer the fermentation time the more biogas produced. Biogas production is influenced by fermentation time because the fermentation time is directly related to the amount of time required to pass through the stages of $\mathrm{CH}_{4}$ formation are hydrolysis, acetogenesis, and methanogenesis. Because each reshuffle takes time enough, so the influence of fermentation time factor on the substrate under anaerobic conditions gives different results on biogas production, the longer the fermentation process increases the biogas production.

\section{Conclusion}

Pursuant to result of research on modification of pyramid-shaped digester for sedimentation stage and beam-shaped with the addition of agitation at fermentation stage in wastewater treatment of POME, it can be concluded: With agitation speeds of $90 \mathrm{rpm}$ and 102, obtained:

The COD value of POME after a 30-day fermentation process was $155 \mathrm{mg} / \mathrm{L}$ for $90 \mathrm{rpm}$ and 113 $\mathrm{mg} / \mathrm{L}$ for $102 \mathrm{rpm}$. These results have met the standard quality of waste that is below $350 \mathrm{mg} / \mathrm{L}$. The BOD value of POME after a 30-day fermentation process was 38.2 $\mathrm{mg} / \mathrm{L}$ for $90 \mathrm{rpm}$ and $38 \mathrm{mg} / \mathrm{L}$ for $102 \mathrm{rpm}$. These results have met the standard quality of waste that is below 100 $\mathrm{mg} / \mathrm{L}$ that has been determined based on the Governor Regulation of South Sumatera No. 8 of 2012 [8].

Percentage of biogas production on days $6^{\text {th }}, 12^{\text {nd }}$, $18^{\text {th }}, 24^{\text {th }}$ and $30^{\text {th }}$ days for agitation speed of $90 \mathrm{rpm}$ that are $5.0234,7.3120,5.0076,14.1043$, and $21.8097 \%$ mole $\mathrm{CH}_{4}$, approximately. The agitation at $102 \mathrm{rpm}$ are $8.4845,10.9531,16.7398,20.7552$, and $26.7552 \%$ mole $\mathrm{CH}_{4}$, approximately on biogas production at day $6^{\text {th }}$, $12^{\text {nd }}, 18^{\text {th }}, 24^{\text {th }}$ and $30^{\text {th }}$ days. Thus biogas production with variations of agitation velocity has an effect on biogas production. While for the optimum biogas production obtained from the digester modifier produced on day 30 with the agitation speed of $102 \mathrm{rpm}$ is 26.5116 $\%$ mole $\mathrm{CH}_{4}$. The $\mathrm{pH}$ value of POME after a 30-day fermentation process is 6.21 for $90 \mathrm{rpm}$ and 6.21 for 102 rpm. These results have met the standard quality of waste that is below $6.0-9.0[8]$.

The authors would like to acknowledge the financial support of penelitian stategis nasional, directorate of research and community service, ministry of research, technology and higher education provides funding research project grants with number SPPK:050/SP2H/LT/DRPM /IV/2017 date 25 april 2017. Also, authors acknowledge for PT. Perkebunan Mitra Ogan was a support of POME.

\section{References}

[1] PT Mitra Ogan Plantation, 2015. Pengolahan Limbah Pabrik Kelapa Sawit. PT. Perkebunan Mitra Ogan. Sumatera Selatan.

[2] Aznury M., A. Trianto, A. Pancoro, and T. Setiadi, (2014) Production of Polyhydroxyalkanoate (PHA) from Palm Oil Mill Effluent (POME), Proceedings International Oil Palm Conference, Bali, 17-19 June

[3] Deublein, D., and A. Steinheuster. 2008. Biogas from Waste and Renewable Resourcers. WileyVHC Verlag GmBH \& CO. KgA, Weinheim.

[4] Aznury, M., Amin, JM., Hasan, A., and Harsyah, A., 2018b. The digester modification for Biogas Production from Palm Oil mill Effluent by Fedbatch, IOP Conf. Series: Earth and Environmental Science 124, 011001. 
[5] Aznury, M., Amin, JM., Hasan, A., and Himmatuliza, A., 2017. Production of Biomethane from Palm Oil mill Effluent with Fed-batch System in Beam-shaped Digester, AIP Conf. Proceedings 1840,110012

[6] Aznury, M., Amin, JM., Hasan, A., and Utomo T.., 2018a. The digester modification for Biogas Production from Palm Oil mill Effluent by batch system, MATEC web of Conference 156,03037

[7] APHA. 1995, Standard Methods for the examination of Water and Wastewater, 19th Ed. Washington, D.C.

[8] Peraturan Gubernur Sumatera Selatan No. 12, 2012, Baku Mutu Limbah Cair bagi Kegiatan Industri, hotel, Rumah Sakit, Domestik dan Pertambangan Batubara, https://peraturan.bpk.go.id/Home/Details/36811 download at June 2017

[9] Zahara, Intan. 2014. Pengaruh Pengaduka Terhdap Produksi Biogas pada Proses Metanogenesis Berbahan Baku Limbah Cair Kelapa Sawit. Skripsi. Jurusan Teknik Kimia, Universitas Utara, Sumatera Utara.

[10] Mujdalipah, Siti, S. Dohong, A. Suryani, and A.Fitria, 2014, Pengaruh Waktu Fermentasi terhadap Produksi Biogas Menggunakan Digester Dua Tahap pada Berbagai Konsentrasi Palm Oil Mill Effluent dan Lumpur Aktif. Skripsi. Program Studi Pendidikan Teknologi Agroindustri, Universitas Pendidikan Indonesia. Bandung.

[11] Widjaja, Tri., Hariani, Natalia, Gunawan, Setio, and Darmawan, (2010), Teknologi Immobilisasi Sel Ca-Alginat Untuk Memproduksi Etanol Secara Fermentasi Kontinyu dengan Zymonas mobilis Termutasi, LaboratoriumTeknologi Biokimia JurusanTeknik Kimia, Fakultas Teknologi Industri Institut Teknologi Sepuluh November, Surabaya.

[12] Rusmana, Iman. 2008. Sistem Operasi Fermentasi, Departemen Biologi FMIPA IPB, Bogor Jawa Barat

[13] Saputri, Hardina Apri. 2015. Pengaruh Persentase Volume Starter dan Waktu Fermentasi pada Pome Terhadap Kuantitas Biogas Menggunakan Digester Balok Sistem Batch, Laporan Akhir. Jurusan Teknik Kimia. Politeknik Negeri Sriwijaya. Palembang

[14] Fahlevi, Muhammad Reza. 2015. Pengaruh Laju Alir Terhadap Waktu Tinggal Pada Digester Berbentuk Limas Secara Batch Dalam Mengolah Air Limbah Industri Kelapa Sawit Menjadi Biogas. Laporan Akhir. Jurusan Teknik Kimia. Politeknik Negeri Sriwijaya. Palembang 